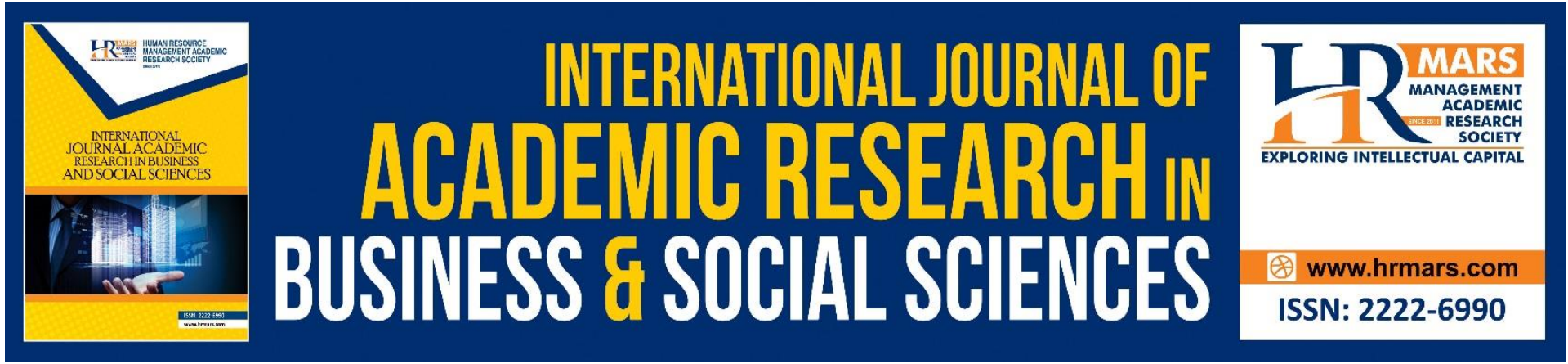

\title{
Child Restraint System: Lessons Learned from Global Best Practices
}

\author{
M. H. MD. Arif Uddin, Kulanthayan KC Mani, Tanveer Ahmed Khan
}

To Link this Article: http://dx.doi.org/10.6007/IJARBSS/v11-i8/10786 DOI:10.6007/IJARBSS/v11-i8/10786

Received: 04 June 2021, Revised: 06 July 2021, Accepted: 25 July 2021

Published Online: 15 August 2021

In-Text Citation: (Uddin et al., 2021)

To Cite this Article: Uddin, M. H. M. A., Mani, K. K., \& Khan, T. A. (2021). Child Restraint System: Lessons Learned from Global Best Practices. International Journal of Academic Research in Business and Social Sciences, 11(8), 904-921.

Copyright: (c) 2021 The Author(s)

Published by Human Resource Management Academic Research Society (www.hrmars.com)

This article is published under the Creative Commons Attribution (CC BY 4.0) license. Anyone may reproduce, distribute, translate and create derivative works of this article (for both commercial and non-commercial purposes), subject to full attribution to the original publication and authors. The full terms of this license may be seen at: http://creativecommons.org/licences/by/4.0/legalcode

Vol. 11, No. 8, 2021, Pg. 904 - 921

http://hrmars.com/index.php/pages/detail/IJARBSS

JOURNAL HOMEPAGE

Full Terms \& Conditions of access and use can be found at http://hrmars.com/index.php/pages/detail/publication-ethics 


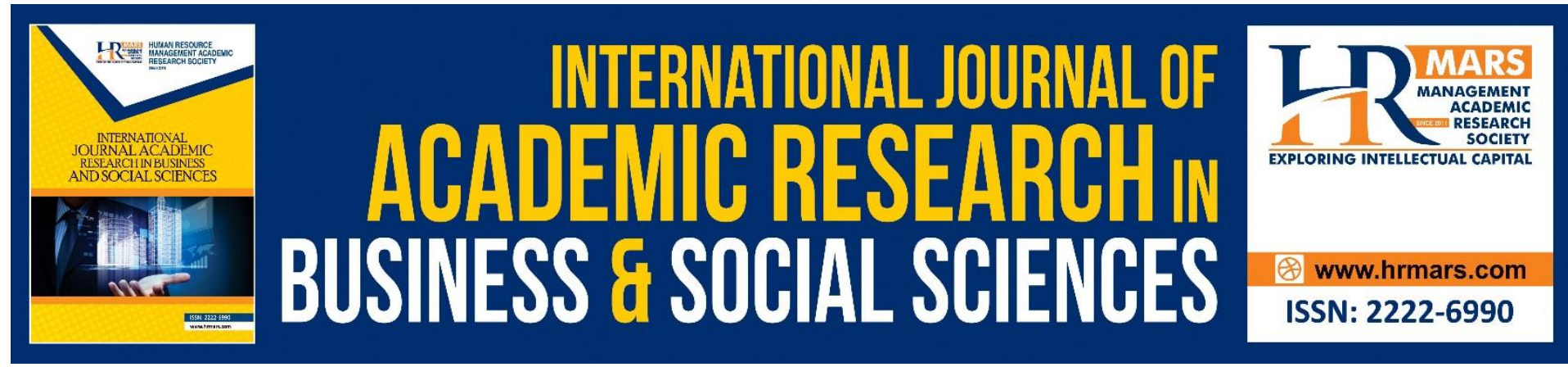

\title{
Child Restraint System: Lessons Learned from Global Best Practices
}

\section{H. MD. Arif Uddin², Kulanthayan KC Mani ${ }^{1,2}$, Tanveer Ahmed Khan ${ }^{3}$}

${ }^{1}$ Institute for Social Science Studies, Putra Infoport, Universiti Putra Malaysia, 43400 UPM Serdang, Selangor, Malaysia, ${ }^{2}$ Safe Kids Malaysia, Universiti Putra Malaysia, ${ }^{3}$ Ohio University, Athens, USA

Email: kulan@upm.edu.my

\begin{abstract}
Road traffic injury is one of the major but neglected public health challenges globally. According to WHO (2018), road crash kills about 1.35 million people while it maims another 50 million, each year globally. Rapid urbanization and industrialization throughout the world have accelerated the growth of transport systems for faster communication. As a result, motor vehicles' mobility has increased to a great extent making roads more vulnerable for road users. Commuters' safety has, therefore, emerged as an issue of critical concern. Automobile manufacturers have taken passenger safety with due importance and have been improvising vehicles' safety measures. The major objective of this paper is to do a literature review of the global best practices. This paper investigates the effectiveness of the current vehicle safety system in ensuring child passengers' safety in a vehicle. Due to the unique physique, traveling children require safety devices that consider their age, height, and weight. An efficient way to improve that safety in moving vehicles is to use Child Restraint Systems (CRS) to 'hold' them during a probable collision. Unfortunately, there is little evidence in lowand middle-income countries (LMICS) relative to high-income countries (HICS). Increasing research on this aspect is vital, especially for LMICs, to make the device more straightforward and effective. This literature review deals with the existing practices regarding child safety in road journeys and probable steps for remedies and improvement, which could eventually be used as a guideline for transferring lessons learned from HICs to LMICs.
\end{abstract}

Keywords: Child Restraint System, Child Safety Seat, Child Restraint Legislation

\section{Introduction}

A considerable amount of mortality and morbidity has been happening globally due to road traffic injury (RTI) (Hyder et al., 2017). Road traffic crashes, the 8th leading cause of global deaths for all age groups, are ranked as the leading cause of deaths of children and young persons (5-29 years) globally. It warrants a shift to the child health issues, which have primarily been denied in road safety. More people are killed on the road than HIV/AIDS, tuberculosis, and diarrheal diseases (WHO, 2018). In RTI, $20 \%$ of victims are children, counted around 262,000 fatalities globally, and 10 million injuries annually (Peden et al., 2004). 
According to Kyu et al (2016), globally, road traffic crash is the first leading cause of death in children between the ages 10 and 19 years while for children aged between 5-9 years, it is the third leading cause of death. For children between ages 1 and 4 years, road crash is the fifteenth leading cause of death. Earlier, the United Nations Children's Fund (2001) report also supports this cause showing that in the OECD (Organization for Economic Co-operation and Development) region, the RTI was the cause of $41 \%$ child fatalities of financially solvent nations. In contrast, that rate in low-income countries (LICS) is three-time higher than that of high-income countries (HICs) (WHO, 2018). Mathers and Loncar (2006) also ranked RTI as the third killer of children of more than five years of age, while reporting it as the 10th killer of the 1-4 year group. Johnston, Rivara, and Soderberg (1994) said that motor vehicle crashes as the leading cause of mortality of children over one year of age. Furthermore, the Centers for Disease Control and Prevention (2002) in the USA also reported that RTI was the leading cause of road users' death older than three years. The report also predicted an approximate hospitalization of 18 children and 400 medication-needing-cases per child mortality due to RTI.

Children have a different physique than adults, which puts them in a more vulnerable condition during RTI (Peden \& Toroyan, 2007). It makes them more vulnerable to head injury due to a different center of gravity (Will, 2011). Abbas, Hefny, and Abu-Zidan (2011) stated that fatality and long-term disability are very common during the injuries that attack victims' head and limb. Sam (2015) said that RTI causes physical and mental damage to children, probably remediable. No one wants to put their child at such a risk, and taking proactive precautions to save them from RTI could be the best approach to keep future generations safer.

In the United States, motor vehicle crashes, which caused 938 fatalities in 2015, are among the leading causes of death for children under 13 years of age (Centers for Disease Control and Prevention, 2017). According to Snowdon et al (2009), motor vehicle crashes injure and kill more children every year in North America than any other cause, with children aged four to eight the most vulnerable. Previous studies have identified several reasons that put this particular age-group of children at risk. The key reasons include parents' lax attention to use booster seats, transitioning their children too quickly from car seats to seat belts etc. Such practices have increased the risk of injury for children traveling ill-guardedly by $153 \%$ (Snowdon, Hussein, \& Ahmed, 2008; Durbin, et al., 2003). Durbin et al (2015) also observed that most injuries and deaths involve unrestrained or incorrectly restrained child passengers.

Restraints in cars (viz. child safety seat, booster seat) are intended to keep the child in his/her place on the seat so that in the event of sudden braking or a crash, the child is not thrown against the interior or out of the car. Age and weight-dependent restraints are designed to withstand crash impacts or evenly distribute the forces over the most substantial child body parts (National Highway Traffic Safety Administration, 2007). Research showed that the absence of those restraints could increase the risk of fatality or severity by $45-74 \%$. The extent varies on the usage of different types of restraints and seating positions (National Highway Traffic Safety Administration, 2010).

Child safety seat (CSS) holds child occupant in place during a crash and protects them from potential injury, hitting any vehicle's internal body parts. It also protects the child-travelers 
from being thrown out of the vehicle. Moreover, those restraints especially consider the child occupant's physique. The design confirms that the potential victim child would be restrained without the dangerous impacts of crash force over vulnerable body parts. On the other hand, widely used lap and shoulder belts within the vehicle designed for adults only and not appropriate for young children.

According to Eby \& Kostyniuk (1999), CSS is mostly three types: infant(for children up to $9 \mathrm{~kg}$ and one year), toddler ( for children from 9-18 kg and up to 1-4 years of age) and booster seats (for children from 18-32 kg and up to 4-7 years of age). They also discussed convertible seats, which could be used for both infants and toddlers, based on the different modes. Type $\mathrm{G}$ restraint (Forward Facing section), a full harness restraint, is used for the 4-8-year-old traveler in Australia, partially replacing booster seats.

The introduction of the child restraint systems has vastly improved children's protection in a motor vehicle from potential injuries in a road crash. However, because of the variation in road infrastructure, frequency of motor vehicles on the streets, traffic laws, different parts of the world face the challenges of child-travelers' protection from the road crash in varied ways. In countries, especially in low-and middle-income countries (LMICs), where traffic rules are weakly regulated but have better road communication infrastructure, child pedestrians face significant injury and fatality risks. Child car occupants are rarely protected with restraints explicitly developed for children. For example, in North America, Australia, and European countries, traffic rules have mandated child restraints compulsory for child occupants. Despite such safety efforts, $32 \%$ of European road traffic fatalities for children up to 14 years of age involved car occupants (Peden et al., 2008). Such a high percentage of child fatalities in road crashes despite improved safety measures calls for continued research and more robust awareness programs and policy activities to make roads further safer for children across the world.

The review paper outlined the existing CRS situation, determining factors in choosing CSS, and illustration of some successful interventions worldwide. To conduct the review, an experienced team consisting of multi-dimensional road safety specialists from the public health and engineering sector reviewed, evaluated, and summarized the literature associated with CSS. Key words used while searching the literatures over internet are child restraint system, child safety seat and child restraint legislation.Various database was explored Scopus, Science Direct and Pubmed. One of the major limitations of the study is that due to a shortage of reliable data, hence secondary data was used for some instances, the study could not identify any distinction between unbelted child fatalities in cars compared to child fatalities as pedestrians, cyclists, or motorcycle riders/passengers.

\section{Usefulness of Child Restraint System}

Motor vehicle crashes affect many young occupants in two ways: either many years lost due to premature death or a life with a disability (Krug et al., 2000). Using restraints for children reduces fatalities and injuries in motor vehicle crashes is well documented. Research showed that proper restrain use could be the best useful tool in reducing the child passenger's fatality and crash severity extent. Previous studies illustrated that appropriate use of child restraints such as CSSs, booster seats, and seat belts could reduce RTI by $45 \%-60 \%$ (Chen et al., 2014; Popoola et al., 2013). Moreover, Abbas et al (2011) added that those child restraints restricted 
the passenger from being injured inside the car or ejected from the car. A study on the outcome of 37,375 patients under the age of 16 involving motor vehicle crashes in the US revealed that in $45.7 \%$ cases, all patients were restrained and injury severity high with a higher risk of emergency surgery in those cases where restraints were not used (Lee et al., 2012).

Research on road safety reveals that CRS, when properly used, lowers the chance of casualty for infants in a motor vehicle crash by 58-71\% (varies on the type of the vehicle) by cushioning the impact of the collision on the child (National Highway Traffic Safety Administration, 2013). CSSs reduce fatal injury by up to $71 \%$ for infants and $54 \%$ for toddlers (National Highway Traffic Safety Administration, 2009; Johnston et al., 1994). Rice and Anderson (2009), who came up with the same findings, observed that proper use of CSS reduces the risk of fatal crashes by $74 \%$ for infants, while for toddlers, the risk is reduced by $59 \%$. Nance et al. (2004) demonstrated that the children, who were sub-optimally restrained, are more than three times less vulnerable to abdominal injury in a crash. According to the Children's Safety Network (2004), every $\$ 46$ CSS could help a family save $\$ 140$ in medical expenses while $\$ 470$ in future earnings and other resource costs, and $\$ 1,300$ in quality of life costs, which is enormous in case of saving.

According to Arbogast, Jermakian, Kallan, and Durbin (2009), best-tailored restraints can avert casualty during the crash by distributing the impact forces over the broad area of the body, shielding the head and backbone and helping the body to slow down. He also argued that child injury mainly occurs due to early graduation to booster seats from CSS, similarly from booster seats to adult safety belts, hastily revolving a child forward, improper use of restraints, and occupying vehicle front seat by children. However, the best impact of these restraints could be associated with proper and correct use. According to Will (2011), CSS should be used and fit it in the best position. He suggested that the back seat is the safest for child occupants in comparison with the front seat.

According to Elliott \& Kallan (2006), In comparison with seat belts, suitably restrained CSS was found associated with a $28 \%$ reduction of fatality risk for the age group of 2 to 6 . Asbridge, Ogilvie, Wilson, \& Hayden (2018) conducted a systematic review along with a meta-analysis of observational studies intending to draw a comparison between CSS and seatbelt. The study also discussed factors associated with the performance of CSS. The result found no significant relation between CSS and seat belt use in motor vehicle crashes for children aged 4 to 8 . In a few cases, CSS has shown more effective than a seat belt. It also showed that a high back booster seat was more effective than a backless booster. However, compared with seatbelt use, booster seat reduced serious injury risks by $45 \%$ for the age group of $4-8$ years (Arbogast et al., 2009).

\section{Existing Knowledge and Practice}

Compared with other transportation issues, only a few studies have been conducted to assess road users' knowledge level about this vital issue. Moreover, in most of the cases, the studies were conducted in the HICs. Hence, the conduction of such a study warrants in the LMICs.

Studies show some misconceptions about using CSS. Research shows that, during the age of four to five, when children outgrow, parents prefer using seatbelt over booster seat to confirm their kids' safety (Safe Kids Canada, 2004). Parents are often unaware that seat belts 
could not guard school-going children in most cases (Ehiri et al., 2006). For illustration, a nationwide Canadian study showed that $75 \%$ of parents secured their child in seat belts because of their wrong perception that the children were physically grown up enough to fit in the regular safety seats designed for the adults (Safe Kids Canada, 2004).

A study by Chaudhry, Sanaullah, Malik, and Klair (2019) conducted on a sample of 622 children from 375 vehicles in Pakistan in 2018 found the usage of only one child safety belt. The study also found that around $43.4 \%$ of children were traveling on the front seat without child safety restraint. A study by Bendak \& Alkhaledi (2017) in UAE observed the practice of using child safety restraint by only $16.7 \%$ of parents from the study sample while traveling with the children. Research conducted by Kakefuda, Yamanaka, Stallones, Motomura, and Nishida (2008a), driving mothers in Japan illustrated bimodal distribution. The study revealed that $45.8 \%$ of mothers used child restraints while going on short distances, while $20.7 \%$ avoided using CSS for their kids. In long-distance driving, $63.6 \%$ of women used safety seats for kids, whereas $15.5 \%$ avoided using CSS. Those data remind the inconsistent use of CSS at various frequencies.

According to crash data gleaned from many studies, the effectiveness of a CRS is contingent upon the appropriate installation of the device in the vehicle, the correct securing of the child in the seat, and the use of an appropriate CRS. International observational studies observed that in several cases, child-travelers are not appropriately restrained. This phenomenon seems to be widespread in North America, Europe, and Australia. Snowdon et al. (2009) observed the rate of CSS use in 2006 and concluded that $90 \%$ of Canadian children were restrained in some restraint. However, only $60 \%$ of these children were tied in the correct safety seat. According to the law, in Australia, riding in a car without proper child restraints is illegal for any child aged 7 or under. In the USA, the age is 6 or under. According to Koppel and Charlton (2009), 79\% of all the inspected restraints had at least one type of misuse. The European project CASPER (2012) have found that $65 \%$ of children have been incorrectly restrained. In $80 \%$ of cases, CSS was wrongly used (Biagioli, 2002). Taft, Mickalide, and Taft (1999) added that $80-90 \%$ CSSs are being misused in the USA, which is proved by national statistics. General Insurance Association of Japan (2003) found that in $44.4 \%$ of cases, the child was not restrained because there was an adult to take care whereas in $38 \%$ cases, the child was not interested in using this. It could be said that in both of these cases, child passenger could be victimized with severe crashes.

Several studies showed that incorrect and/or inappropriate fitment and use of restraints might reduce or nullify their safety benefits and are sources of a higher risk of fatal or severe injuries for children (Kapoor et al., 2011; Bilston \& Brown, 2007; Lesire et al., 2007). Even sometimes, misuse of such a vital safety device may make those virtually useless. It may affect the overall performance of CSS. Although those misuses are negligible in many cases but few other mistakes may make CSS "virtually useless". CSS has been frequently observed being fitted in family vehicles with numerous misuses, which could reduce the device's positive impact. In addition to that, CSS could itself be a hazard for the children as improper use may lead to various injuries: head injury, bone fractures, damage in the cervical spine, liver laceration, and peripheral neuropathy (Lane, Liu, \& Newlin, 2000). 
According to Brown, Grondin, and Potvin (2009), people make mistakes using CSS because of the complicated installation process. Hence, proper research is required to make the system more straightforward and user-friendly. National Highway Traffic Safety Administration (2010) added that more than $95 \%$ of inspected safety seats were found with at least an error while installed in the USA. Significant errors included wrong orientation of seat, incorrect usage of seat belt and fastening clip, misused harness, incorrect use of fir or chest clip.

Another study by Koppel et al (2013) revealed that around $79 \%$ of the sample population ( $\mathrm{N}=$ 2674) projected incorrect or improper use of the child safety restraint, which include: harness strap errors, incorrect use of seat belts, and the inappropriate lock of the buckle clip.

Concerning standard forms of misuse, Koppel and Charlton (2009) ranked harness strap errors (38\%) as the top, followed by seat belt errors (32\%). Besides, missing or incorrect fitting of buckle/locking clip (23\%), missing sash guide (8\%), tether errors (7\%), and wrong size of CSS for the child (6\%) were the common forms of misuses of CSS among others. The study also added that the highest misuse was observed for the forward-facing CSS (88\%), compared to infant seats (67\%) and booster seats or cushions (63\%).

Regarding the availability of awareness-based communication materials for CSS usage, Nakahara, Ichikawa, and Wakai (2007) observed that only $0.35 \%$ of the baby magazine articles in japan cover the procedure of CSS usage. As a result, parents' knowledge regarding such effective safety restraint to protect child occupant has been low. One of the potential reasons for such a low level of knowledge could be the paucity of CSS information following inadequate research on the burning issue. In most cases, parents get this information from the internet. Mass media should ideally be the primary source of CSS information, hardly disseminating pertinent information. Findings from this study largely correspond with those of previous studies, which revealed that for information on a safety seat, parents tend to use unauthentic sources typically from close people or car-seat producers instead of tested sources such as physicians (Snowdon et al., 2009). This indicates that the lack of available knowledge on CSS was the critical reason behind the indifference to using CSS (Carman \& Palancı, 2011).

\section{Associated Factors with Children's Restraint Use}

Certain factors influence the adoption of CRS. Likewise, socioeconomic characteristics have been linked in the research by Olufunlay et al. (2012), conducted in Nigeria through an observational survey in 2007 where a significant correlation was found with CSS use in HICS and LMICs. The study illustrated that CSS is considered a luxury in most LMICs. In most cases, the positive impacts are reduced due to inappropriate use and lack of knowledge in using this device. Few other studies also suggested that users' low awareness level about CSS's positive impact acting as a hindrance in choosing CSS (Mcllvenny et al., 2004). Some other studies have shown that CRS use often depends on the type of CRS and the duration of the trip (Brown et al., 2010). According to Gielen et al. (1984), potential benefits and existing barriers could be the primary determining factor in using CRS. In the US, parents with positive attitudes were more likely to use CRS than parents who held negative attitudes. However, parents mentioned the unwillingness of their children because of discomfort in using such a restrain system. Those factors act as a barrier to using CRS. On the other hand, in the case of Israeli mothers', awareness about the positive impact of using CRS and their positive attitude 
towards using this device were associated positively to increase CRS use (Gofin, Palti, \& Adler, 1990).

The observational study by Bendak \& Alkhaledi (2017) found a lower rate of CRS usage among young, less educated, and male parents. The same population groups portrayed a low percentage of belief in CRS's importance in harm reduction in crashes than other parents' groups. The commonly perceived barriers to correct restraint use revealed by Hall et al. (2018) include difficulties in interpreting instructions and labels; (b) remembering and attending to correct use information; (c) lack of knowledge and behavioral feedback on how to correctly install and use a child restraint; and (d) low confidence in the ability among the users to install and use a child restraint correctly. However, these factors might be different for LMICs as the socioeconomic factor may act as a vital element influencing CRS use.

Monteiro et al. (2013) identified some other factors that include dispositional and contextual that correlate with CRS use. The dispositional characteristics could be drivers' particulars: age, education, and gender, whereas contextual factors could be the vehicle type, place of driving, and period of the day. According to Ojo (2018), using child restraint is influenced by the driver's gender as well as the type of vehicle used and the position of the child seat. With respect to this issue, Snowdon et al. (2008) also added that car seat usage properly seems more for female drivers, drivers' education levels, and users who obtained CSS information after certain hurdles. Pan et al. (2012) revealed that in China, educated women had been found more likely to use seats appropriately for child occupant. Other associated factors in choosing CSS could be decreased among older children; in case of additional vehicle occupants; older vehicles, large vehicle: pickup trucks and van as well as unrestrained new drivers (Greenspan, Dellinger, \& Chen, 2010).

In many cases, affordability effects using CSS. In the USA, drivers with high-income levels use CSS more frequently (Gielen et al., 1984). According to Kulanthayan, Razak, and Schenk (2010), socioeconomic status, such as user's affordability, plays a vital role in deciding appropriate CSS usage for young family members. This is expected that the safety seat should be readily available and cheap to purchase. However, in many countries, those interventions are costly. Peden et al. (2008) mentioned that a factory worker living in a LIC had to work 16 times as long as a HIC counterpart to buy CSS. Purc-Stephensona, Renb, \& Snowdonc (2010) mentioned that in China, the catalyze to purchase a safety seat was to enhance the child occupant safety $(37.1 \%)$, availability of a safety seat $(29.2 \%)$ and price of the safety seat (18.1\%).

Kulanthayan et al (2010) investigated the driver's role in association with using CSS in Malaysia. The study found a strong association among drivers' age, literacy level, and attitude with CSS use. The study also added that using CSS could not be related to the location: rural or urban area whereas researches conducted by Agran et al. (1998) in the United States and by Kostaridou et al. (1997) in Greece could be juxtaposed with the point that they revealed that in rural zone, CSS usage was lower than urban. Age is an important associated factor in Malaysia with CSS usage as drivers more than 40-year-old use CSS for their children less frequently than those below 40 (Kulanthayan et al., 2010). This observation is also supported by other research globally where it mentioned that younger driver uses CSS more than the older driver (Eby et al., 2005). According to the Russell et al (1994), a literate driver is more 
responsive in collecting, assessing and considerate about information and converting them into action. Kulanthayan et al (2010) supported it because drivers who were educated till tertiary level were more likely to use CSS than the drivers who were educated up to the secondary level. Hence, it could be insisted that less educated drivers should be taught in different modules for any intervention design in CSS than educated drivers. According to Sam (2015), drivers who use restraints are more likely to confirm restrained child passengers. Chen et al (2014) added that among male and female drivers, the second group using this system more than the first group for their child passenger. Previous studies show the perception that in rear seats, child occupants are safer, and that's why a certain number of child passenger seats and restrained at the back at rear seats (Durbin \& Committee on Injury and Poison Prevention, 2011). Sam (2015), in his study on 126 drivers who were carrying children to the schools in Dansoman, Accra, observed that the driver might not use child restraint due to few reasons: less ownership on CSS, cost, short trip, less traffic on the road, lack of knowledge on proper using and while adult occupants present.

\section{Role of The Clinicians in Using CRS}

An estimate by Hoffman, Gallardo, and Carlson (2016) concluded that in $95 \%$ of the US, child safety restraint had been misused by parents during the maternity patient's discharge. Arbogast et al (2001) mentioned that clinicians, especially the gynecologists and obstetricians, could play a vital role in spreading updated news about CSS. This is because those professionals act as a resource to the parents. The physician, having latest information about the child passenger safety, should insist using CSS not only for new born baby but also older children as well. They may also play an active role in their affiliated hospital confirm that new born are discharged safely. It may range from finding best suited sit for children as well as how to make the sit best fitted in the care giver's vehicle. However, this might be difficult to have a trained CSS expert in local hospital to confirm all precautions. In that case, local available resource could be used. For optimal safety, every child should use an optimal restraint during that would address both age- and weight during each day trip.

Bull and Sheese (2000) suggested five basic rules for pediatricians to share those learning with parents, confirming child passenger safety in vehicles. These are:

- Airbag could be a hazard itself for children;

- An infant should sit rear faced until they turn to year one and weighs 20 pounds at the minimum;

- Changeable seats from rear to forward-facing must be properly adjusted;

- The safety sit should itself be secured while it is in the vehicle; and

- Child seat would confirm the best safety while the children are adequately fit. In most cases, failure to understand using child seats properly may diminish the best impact of a child seat.

\section{Contribution of Law and Policy in Using CRS}

Child-friendly laws and policies have a significant contribution to increasing CSS use. Literature showed that proper enforcement and advocacy effort is a must to make the best impact of child restraint laws. Belgium and Denmark are the first two countries to implement child restraint legislation (CRL) in 1975. So far, 84 countries have introduced this type of legal instrument (Nazif-Muñoz, 2015). CRL is designed to reduce children's fatalities and injuries by assuring that children are correctly secured in vehicles. Studies that have assessed the impact 
of this type of legislation have been carried out in HICs, including Japan, the USA, Canada and Norway (Desapriya et al., 2004; Brubacher et al., 2016; Elvik et al., 2009). According to these researches, child restraint laws could reduce occupant child fatalities by up to $34 \%$ and occupant child injuries by $15 \%$. CSS laws, which have the best evidence-based recommendations, are the best practical tools for intensifying and proper CSS use (Staunton, 2005). Laws in favor of child restraint have a significant impact on child health as $47 \%$ less severe injury was found for low damage crashes after introducing CSS laws in the USA. For medium- and high-damage crashes, the figure is $31.8 \%$ and $32.4 \%$, respectively (Wagenaar, 1984).

Wagenaar and Webster (1986) showed that child restraint devices' mandatory use could reduce injury significantly for young children. The study, which came up with various observations, shows: CSS has reduced child injury by $28 \%$ while injury per vehicle mile traveled was reduced by $28 \%$, rate of child injury per crashed vehicle was reduced by $27 \%$, and a reduction of $29 \%$ for child injury considering all injured motor vehicle occupants. Evidence also shows that this extensive reduction in damage only occurred among young children occupant than other road users, and it all happened due to focus on the new law. On a different note, parents also believe that such a law might be helpful for their child's mobility. Purc-Stephensona et al. (2010) showed that, in China, most (87.8\%) parents demanded child safety restraint law. Another research in the USA showed that while child restraint law increased the age coverage from 7 to 8 years, CSS/ booster use increased three times, and casualty decreased by $5 \%$ (Eichelberger et al., 2012).

A study by Nazif-Muñoz, Nandi, \& Ruiz-Casares (2018) conducted in Chile highlighted that child restraint law along with national decree on child restraint technical specification decrease the child fatality and injury of the occupant below three years of age. The study also underscored the importance of introducing the laws and regulations of the technical specifications on the child restraint. The study concluded with a recommendation of further research on the factors that affect the adoption of CSS and reform policy. Sam (2015) studied the application of child restraint laws in Ghana and proposed that standalone safety restraint law/ regulation may not safeguard child safety. In addition to that, strict enforcement and education for all road users, especially drivers, may ensure the initiative's best impact. Such research may provide further direction on how CSS could be more effective, backed up by policy and laws in many other countries.

However, the present condition does not illustrate that much hope, especially for the LICs. According to WHO (2018), 84 countries have national child restraint laws, whereas 33 met the child restraints laws' best practice. Among the countries, 53 have a standard of the child restraint, in 113 countries seating in front seats is banned, and 41 countries consider the age/ height criteria for restraint in the legislation. Among best-practicing countries, $85 \%$ exists in the high-income zone, whereas the rest $15 \%$ in the medium-income zone. Unfortunately, no low-income country met the best practice of child restraints.

\section{Successful Evidence Worldwide}

While illustrating successful evidence, the literature suggested three proven initiatives that will increase CRS use and reduce motor vehicle-related mortality and morbidity. These are child passenger restraint laws (Zaza et al., 2001), CSS distribution plus education programs 
(Ehiri et al., 2006), and community-wide information plus improved enforcement movements (Zaza et al., 2001).

Legislation has been shown to increase child restraint use (Snowdon et al., 2009; Winston et al., 2007; Ekman et al., 2001). Wagenaar and Webster (1986) showed clearly the effectiveness of Michigan's mandatory child restraint law in refining child health in the state, reducing motor vehicle crashes by $25 \%$ for child occupant. Studies in the USA by Agran et al (1998) and in Greece, Kostaridou et al (1997) showed compulsory CSS laws contributed significantly to increasing CSS use. Although in Canada, the change has been modest (Snowdon et al., 2008; Snowdon et al., 2009) and exploration of the reasons for non-use found individual economic hardship and a persisting lack of knowledge influenced possible use of child restraints (Snowdon et al., 2009). In Sweden, jurisdictions where promotion and loan schemes had supported the legislation, have achieved the highest age-appropriate child restraint use (Ekman et al., 2001). Therefore, it could be said that proper advocacy tools backed by legislation and enforcement could be an integral approach globally to increase CRS usage.

In a simulation study, Rola \& Rzymkowski (2015) demonstrated that a properly installed safety restraint might improve child passenger safety in frontal crashes. He also added that an airbag, retractor, and a smart pre-tensioner are additional restraints that work successfully combined with a correctly oriented child restraint system that would address the size, weight, and stages of growth of a child's physique. According to Kakefuda et al (2008b), CSS, one of Japan's prime health concerns, was emphasized on advertising only during the intervention. The writing enforced that merely advertisement could not make a sustainable solution; instead, educational components would back it for multiple stakeholders. It also added that CSS use barriers should be addressed clearly for any kind of intervention design in CSS.

Education programs are effective in increasing the use of appropriate child restraints (Zaza et al., 2001), but inadequate responses have been reported in minority groups (Thoreson et al., 2009). Therefore, it is essential to understand the factors associated with inappropriate child restraint use in a specific population. Nance et al. (2004) felt the importance of aggressive educational campaigns that would aim to get child occupant to restrain system and the importance of optimal use of restraint. Instead of a restrain use message, the campaigns should insist on age-specific restraint use.

Ebel et al (2003) suggested a locality-based comprehensive countermeasures approach that involved:

- Development of community alliance of various stakeholders to encourage the use of booster seats;

- Community advisory committee, consisting of parents and caregivers who would contribute through responding to communicative materials and to develop policies to ensure active community participation;

- Extensive community awareness program to enhance knowledge and awareness of the necessity of using a booster seat with the help of different communication materials which will address other age group and diversified community;

- Educational programs to address challenges to booster seat use as well as defining types of booster seats, identifying available devices, and providing alternatives solution and discount booster seat prices; and 
- In-services training programs for the health professional, child care professional, law enforcement, emergency medical service employees, and advocates of child passenger safe

Bull and Sheese (2000) mentioned that taking proactive initiative: the improvisation of CSS and design of the vehicle, comprehensive education program involving multiple stakeholders and proper enforcement of existing laws helped reduce child mortality in the USA for the last two decades. However, the contribution of such an initiative in lowering child mortality could be checked in other LMICs.

\section{Conclusions}

The above results reflect current trends in the usage of child restraint. Although most of the studies conducted in HICs evidence that substantial inappropriate restraint remains, which demands strong consideration. In comparison to unrestrained children or adult seatbelts, properly restrained children are less likely to be injured or killed in road crashes. However, the restraint should consider the size and weight of the child passenger. Properly fitted and user-specific child restraints should be ensured by legislation. All initiatives should be backed by steady enforcement and community education. Those education programs should include parents having an infant and young children and those potential parents expecting a new baby.

Moreover, behavior change interventions may start from the hospital targeting new parents. As for LMICs, cost of child restraints act as a catalyst on usage rate; attention needs to be drawn to the design issue of child restraint seat to make it more cost-effective. Subsidies by the government and developing local solutions would be helpful in LMICs. This will help continue sustained efforts about appropriate restraint to maintain and improve the gains achieved in proper child restraint use.

The development program needs to be designed appropriately to make the awareness and advocacy effort more effective and devise appropriate monitoring and evolution tools. Effort should be given on continuous data collection and analysis of child restraint usage rates to confirm the best evaluation of all policies and programs' impact. Substantially, those learnings should be incorporated into new project planning.

However, in the LMICs with different socioeconomic settings and various traffic conditions, barely any comprehensive study has been conducted on existing practices. Therefore, there remains an abundant scope for further research in those countries that can help address the local settings' traffic needs instead of extrapolating findings from the study conducted in different environments like the HICs.

\section{References}

Abbas, A. K., Hefny, A. F., \& Abu-Zidan, F. M. (2011). Seatbelts and road traffic collision injuries. World Journal of Emergency Surgery, 6(1), 18-27.

Agran, P. F., Anderson, C. L., \& Winn, D. G. (1998). Factors associated with restraint use of children in fatal crashes. Pediatrics, 102(3), E39. Retrieved from https://doi.org/10.1542/PEDS.102.3.E39

Arbogast, K. B., Jermakian, J. S., Kallan, M. J., \& Durbin, D. R. (2009). Effectiveness of Belt Positioning Booster Seats: An Updated Assessment. Pediatrics, 124(5), 1281-1286. 
Retrieved from https://doi.org/10.1542/peds.2009-0908

Arbogast, K. B., Moll, E. K., Morris, S. D., \& Winston, F. K. (2001). Child occupant protection: a summary of current safety recommendations. Primary Care Update for Ob/Gyns, 8(4), 141-148. Retrieved from https://doi.org/10.1016/s1068-607x(01)00074-9

Asbridge, M., Ogilvie, R., Wilson, M., \& Hayden, J. (2018). The impact of booster seat use on child injury and mortality: Systematic review and meta-analysis of observational studies of booster seat effectiveness. Accident Analysis and Prevention, 119(2), 50-57. Retrieved from https://doi.org/10.1016/j.aap.2018.07.004

Bendak, S., \& Alkhaledi, K. (2017). Child restraint system use in the United Arab Emirates. Transportation Research Part F: Traffic Psychology and Behaviour, 51 (1), 65-72. Retrieved from https://doi.org/10.1016/j.trf.2017.09.001

Biagioli F. (2002). Proper use of child safety seats. American Family Physician, 65(10), 20852090.

Bilston, L., \& Brown, J. (2007). Child restraint misuse: incorrect and inappropriate use of restraints by children reduces their effectiveness in crashes. Journal of the Australasian College of Road Safety, 18(3), 34-43.

Brown, J., Wainohu, D., Aquilina, P., Suratno, B., Kelly, P., \& Bilston, L. E. (2010). Accessory child safety harnesses: Do the risks outweigh the benefits? Accident Analysis and Prevention, 42(1), 112-121. Retrieved from https://doi.org/10.1016/j.aap.2009.07.011

Brown, S. H. M., Grondin, D. E., \& Potvin, J. R. (2009). Strength limitations to proper child safety seat installation: Implications for child safety. Applied Ergonomics, 40(4), 617-621.

Brubacher, J. R., Desapriya, E., Erdelyi, S., \& Chan, H. (2016). The impact of child safety restraint legislation on child injuries in police-reported motor vehicle collisions in British Columbia: An interrupted time series analysis. Paediatrics \& Child Health, 21(4), e27e31.

Bull, M. J., \& Sheese, J. (2000). Update for the pediatrician on child passenger safety: five principles for safer travel. Pediatrics, 106(5), 1113-1116. Retrieved from https://doi.org/10.1542/peds.106.5.1113

Carman, K. B., \& Palancı, Y. (2011). The use of child safety seats: A survey on levels of knowledge and attitudes of university employees. Journal of Clinical and Experimental Investigations, 2(2), 157-160. Retrieved from https://doi.org/10.5799/ahinjs.01.2011.02.0006

CASPER Project. (2012). Child Advanced Safety Project for European Roads. Retrieved from https://cordis.europa.eu/project/id/218564/reporting

Centers for Disease Control and Prevention. (2002). Web-based injury statistics query and reporting system (WISQARS). Retrieved from www. Cdc. Gov/Ncipc/Wisqars.

Centers for Disease Control and Prevention. (2017). WISQARS (Web-Based Injury Statistics Query and Reporting System). Retrieved from https://www.cdc.gov/injury/wisqars/index.\%0Ahtml.

Chaudhry, A., Sanaullah, I., Malik, B. Z., \& Klair, A. A. (2019). An investigation of awareness, perceptions, and usage of child car seats in Pakistan. Journal of Transport and Health, 13(1), 247-258. Retrieved from https://doi.org/10.1016/j.jth.2019.05.001

Chen, X., Yang, J., Peek-Asa, C., McGehee, D. V., \& Li, L. (2014). Parents' knowledge, attitude, and use of child restraints, Shantou, China. American Journal of Preventive Medicine, 46(1), 85-88. Retrieved from https://doi.org/10.1016/j.amepre.2013.08.017

Children's Safety Network. (2004). Child Safety Seats : How Large are the Benefits and Who Should Pay ? Retrieved from 
https://www.childrenssafetynetwork.org/sites/default/files/child_safety_seats_childho od_injury_cost_prevention.pdf

Desapriya, E. B. R., Iwase, N., Pike, I., Brussoni, M., \& Papsdorf, M. (2004). Child motor vehicle occupant and pedestrian casualties before and after enactment of child restraint seats legislation in Japan. Injury Control and Safety Promotion, 11(4), 225-230.

Durbin, D. R., \& Committee on Injury and Poison Prevention, V. (2011). Child passenger safety. Pediatrics, 127(4), 788-793. https://doi.org/10.1542/peds.2011-0213

Durbin, D. R., Elliott, M. R., \& Winston, F. K. (2003). Belt-Positioning Booster Seats and Reduction in Risk of Injury among Children in Vehicle Crashes. Journal of the American Medical Association, 289(21), 2835-2840. Retrieved from https://doi.org/10.1001/jama.289.21.2835

Durbin, D. R., Jermakian, J. S., Kallan, M. J., McCartt, A. T., Arbogast, K. B., Zonfrillo, M. R., \& Myers, R. K. (2015). Rear seat safety: variation in protection by occupant, crash and vehicle characteristics. Accident Analysis \& Prevention, 80(2), 185-192.

Ebel, B. E., Koepsell, T. D., Bennett, E. E., \& Rivara, F. P. (2003). Use of child booster seats in motor vehicles following a community campaign: a controlled trial. JAMA, 289(7), 879884.

Eby, D. W., Bingham, C. R., Vivoda, J. M., \& Ragunathan, T. (2005). Use of booster seats by Michigan children 4-8 years of age. Accident Analysis \& Prevention, 37(6), 1153-1161.

Eby, D. W., \& Kostyniuk, L. P. (1999). A statewide analysis of child safety seat use and misuse in Michigan. Accident; Analysis and Prevention, 31(5), 555-566. Retrieved from https://doi.org/10.1016/s0001-4575(99)00012-3

Ehiri, J. E., Ejere, H. O., Magnussen, L., Emusu, D., King, W., \& Osberg, S. J. (2006). Interventions for promoting booster seat use in four to eight year olds travelling in motor vehicles. Cochrane Database of Systematic Reviews, 888(3), 854-888. Retrieved from https://doi.org/10.1002/14651858.CD004334.pub2

Eichelberger, A. H., Chouinard, A. O., \& Jermakian, J. S. (2012). Effects of booster seat laws on injury risk among children in crashes. Traffic Injury Prevention, 13(6), 631-639.

Ekman, R., Welander, G., Svanström, L., \& Schelp, L. (2001). Long-term effects of legislation and local promotion of child restraint use in motor vehicles in Sweden. Accident Analysis \& Prevention, 33(6), 793-797.

Elliott, M. R., Kallan, M. J., Durbin, D. R., \& Winston, F. K. (2006). Effectiveness of child safety seats vs seat belts in reducing risk for death in children in passenger vehicle crashes. Archives of Pediatrics \& Adolescent Medicine, 160(6), 617-621. Retrieved from https://doi.org/10.1001/archpedi.160.6.617

Elvik, R., Vaa, T., Hoye, A., \& Sorensen, M. (2009). The handbook of road safety measures: Emerald Group Publishing, Inc. Retrieved from https://silo.pub/handbook-of-roadsafety-measures-second-edition.html

General Insurance Association of Japan. (2003). A study on child seat use and attitude. Retrieved from https://www.sonpo.or.jp/en/

Gielen, A. C., Eriksen, M. P., Daltroy, L. H., \& Rost, K. (1984). Factors associated with the use of child restraint devices. Health Education Quarterly, 11(2), 195-206.

Gofin, R., Palti, H., \& Adler, B. (1990). The use of car restraints by newborns and mothers: knowledge, attitudes, and practices. Israel Journal of Medical Sciences, 26(5), 261-266.

Greenspan, A. I., Dellinger, A. M., \& Chen, J. (2010). Restraint use and seating position among children less than 13 years of age: Is it still a problem? Journal of Safety Research, 41(2), 183-185. 
Hall, A., Ho, C., Keay, L., McCaffery, K., Hunter, K., Charlton, J. L., ... Brown, J. (2018). Barriers to correct child restraint use: A qualitative study of child restraint users and their needs. Safety Science, 109(1), 186-194. Retrieved from https://doi.org/10.1016/j.ssci.2018.05.017

Hoffman, B. D., Gallardo, A. R., \& Carlson, K. F. (2016). Unsafe from the Start: Serious Misuse of Car Safety Seats at Newborn Discharge. Journal of Pediatrics, 171, 48-54. Retrieved from https://doi.org/10.1016/j.jpeds.2015.11.047

Hyder, A. A., Paichadze, N., Toroyan, T., \& Peden, M. M. (2017). Monitoring the decade of action for global road safety 2011-2020: an update. Global Public Health, 12(12), 14921505.

Johnston, C., Rivara, F. P., \& Soderberg, R. (1994). Children in car crashes: analysis of data for injury and use of restraints. Pediatrics, 93(6), 960-965.

Kakefuda, I., Yamanaka, T., Stallones, L., Motomura, Y., \& Nishida, Y. (2008a). Child restraint seat use behavior and attitude among Japanese mothers. Accident Analysis and Prevention, 40(3), 1234-1243. Retrieved from https://doi.org/10.1016/j.aap.2008.01.013

Kakefuda, I., Yamanaka, T., Stallones, L., Motomura, Y., \& Nishida, Y. (2008b). Child restraint seat use behavior and attitude among Japanese mothers. Accident Analysis \& Prevention, 40(3), 1234-1243.

Kapoor, T., Altenhof, W., Snowdon, A., Howard, A., Rasico, J., Zhu, F., \& Baggio, D. (2011). A numerical investigation into the effect of CRS misuse on the injury potential of children in frontal and side impact crashes. Accident Analysis \& Prevention, 43(4), 1438-1450.

Koppel, S., Charlton, J. L., \& Rudin-Brown, C. M. (2013). The Impact of New Legislation on Child Restraint System (CRS) Misuse and Inappropriate Use in Australia. Traffic Injury Prevention, 14(4), 387-396. Retrieved from https://doi.org/10.1080/15389588.2012.700746

Koppel, S., \& Charlton, J. L. (2009). Child restraint system misuse and/or inappropriate use in Australia. Traffic Injury Prevention, 10(3), 302-307. Retrieved from https://doi.org/10.1080/15389580902856392

Kostaridou, S., Anastasea-Vlachou, K., Sotiropoulou, F., Panagopoulou, G., Panagopoulou, M., Papathanasiou-Klontza, D., \& Xipolita-Zachariadi, A. (1997). Car transportation conditions of preschool children: use of children's car safety seats. Acta Paediatrica, 86(2), 192-195.

Krug, E. G., Sharma, G. K., \& Lozano, R. (2000). The global burden of injuries. American Journal of Public Health, 90(4), 523-532.

Kulanthayan, S., Razak, A., \& Schenk, E. (2010). Driver characteristics associated with child safety seat usage in Malaysia: A cross-sectional study. Accident Analysis and Prevention, 42(2), 509-514. Retrieved from https://doi.org/10.1016/j.aap.2009.09.015

Kyu, H. H., Pinho, C., Wagner, J. A., Brown, J. C., Bertozzi-Villa, A., Charlson, F. J., ... Ferrari, A. J. (2016). Global and national burden of diseases and injuries among children and adolescents between 1990 and 2013: findings from the global burden of disease 2013 study. JAMA Pediatrics, 170(3), 267-287.

Lane, W. G., Liu, G. C., \& Newlin, E. (2000). The association between hands-on instruction and proper child safety seat installation. Pediatrics, 106(4), 924-929.

Lee, S. L., Yaghoubian, A., Stark, R., Munoz, V., \& Kaji, A. H. (2012). Are there racial disparities in the use of restraints and outcomes in children after motor vehicle crashes? Journal of Pediatric Surgery, 47(6), 1192-1195. 
Lesire, P., Cuny, S., Alonzo, F., Tejera, G., \& Cataldi, M. (2007). Misuse of child restraint systems in crash situations - danger and possible consequences. Annual proceedings. Association for the Advancement of Automotive Medicine, 51, 207-222.

Mathers, C. D., \& Loncar, D. (2006). Projections of global mortality and burden of disease from 2002 to 2030. PLoS Medicine, 3(11), e442.

Mcllvenny, S., Al Mahrouqi, F., Al Busaidi, T., Al Nabhani, A., Al Hikmani, F., Al Kharousi, Z., ... Al Lawati, A. (2004). Rear seat belt use as an indicator of safe road behaviour in a rapidly developing country. The Journal of the Royal Society for the Promotion of Health, 124(6), 280-283.

Monteiro, N. M., Balogun, S. K., Tlhabano, K. N., \& Pheko, M. (2013). I Love My Baby Even unto Death: Child Safety Restraint Use among Drivers in Gaborone, Botswana. American Journal of Rural Development, 1(4), 62-69.

Nakahara, S., Ichikawa, M., \& Wakai, S. (2007). Magazine information on safety belt use for pregnant women and young children. Accident Analysis \& Prevention, 39(2), 356-363.

Nance, M. L., Lutz, N., Arbogast, K. B., Cornejo, R. A., Kallan, M. J., Winston, F. K., \& Durbin, D. R. (2004). Optimal Restraint Reduces the Risk of Abdominal Injury in Children Involved in Motor Vehicle Crashes. Annals of Surgery, 239(1), 127-131. Retrieved from https://doi.org/10.1097/01.sla.0000103068.51037.20

National Highway Traffic Safety Administration. (2007). National Child Passenger Safety Certification Training Program, Student Manual. Retrieved from https://www.yumpu.com/en/document/read/41419386/student-manual-nationalchild-passenger-safety-board

National Highway Traffic Safety Administration. (2009). CSA Technical Report: The 2006 National Survey of the Use of Booster Seats-Methodology. Retrieved from https://crashstats.nhtsa.dot.gov/Api/Public/ViewPublication/811111

National Highway Traffic Safety Administration. (2010). Traffic safety facts: Children. Retrieved from https://crashstats.nhtsa.dot.gov/Api/Public/ViewPublication/811641

National Highway Traffic Safety Administration. (2013). Counter measures that works: Highway Safety Countermeasure Guide for State Highway Safety Officers. Retrieved from https://www.nhtsa.gov/sites/nhtsa.gov/files/documents/812478_countermeasuresthat-work-a-highway-safety-countermeasures-guide-.pdf

Nazif-Muñoz, J. I. (2015). Did child restraint laws globally converge? Examining 40 years of policy diffusion. Traffic Injury Prevention, 16(2), S32-S40.

Nazif-Muñoz, J. I., Nandi, A., \& Ruiz-Casares, M. (2018). Impact of child restraint policies on child occupant fatalities and injuries in Chile and its regions: an interrupted time-series study. Accident Analysis \& Prevention, 120 (2), 38-45.

Ojo, T. K. (2018). Seat belt and child restraint use in a developing country metropolitan city. Accident Analysis and Prevention, 113(3), 325-329. Retrieved from https://doi.org/10.1016/j.aap.2018.02.008

Olufunlayo, T. F., Odeyemi, K. A., Ogunnowo, B. E., Onajole, A. T., \& Oyediran, M. A. (2012). An observational survey of child car safety practices in private pre-primary and primary schools in two local government areas of lagos state, Nigeria. Injury Prevention, 18(4), 216-220. Retrieved from https://doi.org/10.1136/injuryprev-2011-040047

Pan, S., Du, W., Jiang, F., Bilston, L. E., Brown, J., \& Shen, X. (2012). Exploring child car passenger safety practices in China: experience from a parental survey in Shanghai. Injury Prevention, 18(2), 133-137.

Peden, M., Oyegbite, K., Ozanne-Smith, J., Hyder, A. A., Branche, C., Rahman, A., Rivara, F., \& 
Bartolomeos, K. (Eds.). (2008). World Report on Child Injury Prevention. World Health Organization.

Popoola, S. O., Oluwadiya, K. S., Kortor, J. N., Denen-Akaa, P., \& Onyemaechi, N. O. C. (2013). Compliance with seat belt use in Makurdi, Nigeria: An observational study. Annals of Medical and Health Sciences Research, 3(3), 427-432.

Purc-Stephensona, R. J., Renb, J., \& Snowdonc, A. W. (2010). An exploratory study of parents' use and knowledge of car safety seats in Beijing, China. International Journal of Injury Control and Safety Promotion, 17(4), 231-238. Retrieved from https://doi.org/10.1080/17457300.2010.487155

Rice, T. M., \& Anderson, C. L. (2009). The effectiveness of child restraint systems for children aged 3 years or younger during motor vehicle collisions: 1996 to 2005. American Journal of Public Health, 99(2), 252-257. Retrieved from https://doi.org/10.2105/AJPH.2007.131128

Rola, E., \& Rzymkowski, C. (2015). Effectiveness of the child restraint system with a special airbag and smart seatbelt pretensioner in frontal collisions. 2015 IRCOBI Conference Proceedings - International Research Council on the Biomechanics of Injury, 101-113. Retrieved from https://www.scopus.com/inward/record.uri?eid=2-s2.084996761418\&partnerID $=40 \&$ md5=52facabb1fa7b6dce2c7903a96c6241d

Russell, J., Kresnow, M. J., \& Brackbill, R. (1994). The effect of adult belt laws and other factors on restraint use for children under age 11. Accident Analysis and Prevention, 26(3), 287295. https://doi.org/10.1016/0001-4575(94)90002-7

Safe Kids Canada. (2004). Booster seat use in Canada: A national challenge. Retrieved from https://parachute.ca/en/program/safe-kids-week/

Sam, E. F. (2015). Don't learn safety by accident: A survey of child safety restraint usage among drivers in Dansoman, Accra. Journal of Transport and Health, 2(2), 160-165. Retrieved from https://doi.org/10.1016/j.jth.2014.08.003

Snowdon, A. W., Hussein, A. A., \& Ahmed, S. E. (2008). Children at risk: Predictors of car safety seat misuse in Ontario. Accident Analysis and Prevention, 40(4), 1418-1423. Retrieved from https://doi.org/10.1016/j.aap.2008.03.004

Snowdon, A. W., Hussein, A., Purc-Stevenson, R., Bruce, B., Kolga, C., Boase, P., \& Howard, A. (2009). Are we there yet? Canada's progress towards achieving road safety vision 2010 for children travelling in vehicles. International Journal of Injury Control and Safety Promotion, 16(4), 231-237.

Staunton, C. (2005). Critical Gaps in Child Passenger Safety Practices, Surveillance, and Legislation: Georgia, 2001. Pediatrics, 115(2), 372-379. Retrieved from https://doi.org/10.1542/peds.2004-0530

Taft, C. H., Mickalide, A. D., \& Taft, A. R. (1999). Child passengers at risk in America: a national study of car seat misuse. Journal of the International Society for Child and Adolescent Injury Prevention, 8(4), 284-288. Retrieved from https://doi.org/10.1136/ip.8.4.284

Thoreson, S., Myers, L., Goss, C., \& DiGuiseppi, C. (2009). Effects of a booster seat education and distribution program in child care centers on child restraint use among children aged 4 to 8 years. Archives of Pediatrics \& Adolescent Medicine, 163(3), 261-267.

United Nations International Children's Emergency Fund. (2001). Child deaths by injury in rich nations. UNICEF, Innocent report card, 2. Available online https://www.unicefirc.org/publications/pdf/repcard2e.pdf

Wagenaar, A. C. (1987). Effects of child restraint laws on traffic fatalities in eleven states. The Journal of trauma, 27(7), 726-732. Retrieved from https://doi.org/10.1097/00005373- 
198707000-00006

Wagenaar, A. C., Tobler, A. L., \& Komro, K. A. (2010). Effects of alcohol tax and price policies on morbidity and mortality: a systematic review. American journal of public health, 100(11), 2270-2278. Retrieved from https://doi.org/10.2105/AJPH.2009.186007

Wagenaar, A. C., \& Webster, D. W. (1986). Preventing injuries to children through compulsory automobile safety seat use. Pediatrics, 78(4), 662-672.

World Health Organization. (2018). Global status report on road safety. Geneva: World Health Organization. Available online https://www.who.int/publications/i/item/9789241565684

Winston, F. K., Kallan, M. J., Elliott, M. R., Xie, D., \& Durbin, D. R. (2007). Effect of booster seat laws on appropriate restraint use by children 4 to 7 years old involved in crashes. Archives of Pediatrics \& Adolescent Medicine, 161(3), 270-275.

Zaza, S., Sleet, D. A., Thompson, R. S., Sosin, D. M., Bolen, J. C., \& Task Force on Community Preventive Services. (2001). Reviews of evidence regarding interventions to increase use of child safety seats. American Journal of Preventive Medicine, 21(4), 31-47. Retrieved from https://doi.org/10.1016/s0749-3797(01)00377-4 